\title{
Pro-active Drug Facilitated Sexual Assault Using Sedative - hypnotic Medication
}

\begin{abstract}
ANA FULGA, ANCA IULIA NEAGU*, ANAMARIA CIUBARA, CARMINA LIANA MUSAT, MARIUS NEAGU*, IULIU FULGA
Dunarea de J os University of Galati, School of Medicine and Pharmacology 35 Cuza Str., Galati 800010, Romania

Drug facilitated sexual assault (DFSA) can be defined as sexual activity occurring where consent is invalid or absent due to the effects of drugs and/or alcohol. We report a rare case of pro-active drug facilitated sexual assault involving non-oral administration of sedative-hypnotic intoxicant without primary alcoholic ingestion. For eight years, a male nurse administered sedative-hypnotic drugs to patients admitted to the hospital unit, in order to subsequently maintain sexual intercourse with them. The intravenous administration without primary alcoholic ingestion distinguishes this case of pro-active drug facilitated sexual assault from those presented in associated literature.
\end{abstract}

Keywords: Drug facilitated sexual assault; Benzodiazepines; Barbiturates

Drug facilitated sexual assault (DFSA) can be defined as sexual activity occurring where consent is invalid or absent due to the effects of drugs and/or alcohol [1-6].

Drugs used in DFSA need to have certain characteristics both in terms of how they are administered and the effect they cause on the victim including (i) causing sedation and/or anterograde amnesia; (ii) being odourless and tasteless; (iii) dissolving readily in beverages; (iv) being rapidly absorbed after oral administration, and (v) being rapidly cleared from the body (within $24 \mathrm{~h}$ ) $[7,8]$. These substances may be self-administered by the victim (opportunistic DFSA) or administered by the offender (predatory/pro-active DFSA).

This report presents a rare case of pro-active drug facilitated sexual assault involving non-oral administration of sedative-hypnotic intoxicant without primary alcoholic ingestion.

\section{Experimental part}

In 2015, a teenage girl previously admitted to the Surgery Unit of the Emergency Hospital denounces a male nurse for rape. The medical attendant entered the room at night and intravenously administered the victim an unknown injectable substance without previously notifying it's name or use. During the administration, the aggressor started a dialogue with the underaged patient, asking her, amongst other subjects, whether she was sexually active. All this time, the victim felt inert, drowsy, unable to react or ask for help, but did not lose consciousness and realized she was being sexually abused.

The DNA exam confirmed the presence of sperm, which belonged to the offender, in the victim's vaginal discharge. No biological tests were collected for toxicological examination in order to establish the presence or the quantitive values of the sedative-hypnotic substances. As it follows from the hospital records, at the time of the victim's hospitalization, the medical unit was equipped with sedative drugs belonging to barbiturates and benzodiazepines class.

Police extended the investigation and subsequently discovered that, for eight years, the same nurse administered sedative-hypnotic drugs to the patients admitted to the hospital unit, in order to maintain sexual intercourse with them, related and witnessed aspect in conjuction with their medical records, doctors' statements, drug prescriptions and other hospital's available documents. Police has heard the testimony of dozens of patients who have been previously admitted to the Emergency Hospital's Surgery Unit since 2010, all confirming the nurse's behaviour.

\section{Results and discussions}

Benzodiazepines are a class of drugs which exhibit depressant properties on the CNS. Their medical purposes are mainly the treatment of anxiety and insomnia. This class is found in forms of capsules, tablets and injectables [9].

The applicable properties for DFSA, manifested by benzodiazepines intake, are sleepiness, fatigue, dizziness, impaired coordination and/or thinking, memory loss, drowsiness and confusion [14-18]. Benzodiazepines are compounds with lipophilic properties, therefore they are less soluble in polar solvents, as in ethanol and water. There is a connection between the solubility of lipids and the onset time, for example, the more lipid-soluble the drugs are, the faster the onset time will be (Table 1). The onset time ranges from a few minutes (for nitrazepam, lorazepam) up to 1.5 hours (for diazepam, temazepam). So contaminated drinks with lorazepam or nitrazepam will start taking action a lot more quickly than those contaminated with either diazepam or temazepam. Benzodiazepines half-lives can vary from long acting (100 hours for diazepam) to short acting ( 3 hours for

\begin{tabular}{|l|l|l|l|}
\hline Compound & Form & $\begin{array}{l}\text { Solubility: } \\
\text { Water }\end{array}$ & $\begin{array}{l}\text { Solubility: } \\
\text { ethanol }\end{array}$ \\
\hline Diazepam & $\begin{array}{l}\text { Tablets, capsules, } \\
\text { injectables }\end{array}$ & Slightly solubie & Soluble \\
\hline Flunitrazepam & & Sparingly soluble & Slightly solubie \\
\hline Lorazepam & & Insoluble & Sparingly soluble \\
\hline Nitrazepam & & Practically imsoluble & Slightly solubie \\
\hline Temazepam & & Practically mooluble/very slightly solubie & Soluble freely soluble \\
\hline
\end{tabular}

Table 1

PHYSICAL PROPERTIES OF SELECTED BENZODIAZEPINES AND THEIR

SOLUBILITY [9-13]

* email: ancazanoschi@gmail.com, Phone: 0754937354 ; mariusneagu87@gmail.com, Phone: 0745212079 
Table 2

HALF-LIFE, ONSET AND APPLIED DOSES FOR SELECTED BENZODIAZEPINES (TOXIC DOSES ARE NOT KNOWN) $[9,10,14]$

\begin{tabular}{|c|c|c|c|c|}
\hline Compound & $\begin{array}{l}\text { Onset } \\
(\min )\end{array}$ & $\begin{array}{l}\text { Half-life } \\
\text { (h) }\end{array}$ & Major metabolites & $\begin{array}{l}\text { Phamaceutical/therapeutic } \\
\text { doge }\end{array}$ \\
\hline Diazepam & $30-90$ & $20-100$ & $\begin{array}{l}\text { Desmethyldiazepam (active); oxazepam (active); temazepam } \\
\text { (active) }\end{array}$ & $5-30 \mathrm{mg}$ \\
\hline Lorazepam & $5-30$ & $9-24$ & Glucuronide conjugate of lorazepam (mactive) & $1-10 \mathrm{mg}$ \\
\hline Temazepam & $20-90$ & $8-15$ & Glucuronide conjugate of temazepam (inactive) & $\begin{array}{l}\text { 1-20 mg (insomnia); } \\
20-40 \mathrm{mg} \text { (premedication) }\end{array}$ \\
\hline
\end{tabular}

\begin{tabular}{|l|l|l|l|}
\hline Compound & Form & $\begin{array}{l}\text { Solubility: } \\
\text { Water }\end{array}$ & $\begin{array}{l}\text { Solubility: } \\
\text { ethanol }\end{array}$ \\
\hline Amobarbital & $\begin{array}{l}\text { Tablets, capsules, } \\
\text { injectables }\end{array}$ & Very slightly solubie & Freely soluble \\
\hline Barbital & & Slightly solubie & Soluble \\
\hline $\begin{array}{l}\text { Pentobarbital } \\
\text { Phenobarbital }\end{array}$ & & Very slightly solubie & Freely soluble \\
\hline Secobarbital & & Slightly solubie & Freely soluble \\
\hline
\end{tabular}

Table 3

PHYSICAL PROPERTIES OF SELECTED BARBITURATES AND THEIR SOLUBILITY $[9,10]$

\section{Table 4}

HALF-LIFE, ONSET AND APPLIED DOSES FOR SELECTED BARBITURATES (TOXIC DOSES ARE NOT KNOWN) $[9,10,14,15]$

\begin{tabular}{|c|c|c|c|c|c|}
\hline Compound & $\begin{array}{l}\text { Onset } \\
(\mathrm{min})\end{array}$ & $\begin{array}{l}\text { Half-life } \\
\text { (h) }\end{array}$ & Major metabolites & $\begin{array}{l}\text { Phamaceutical } \\
\text { therapeutic dose }\end{array}$ & Toxic \\
\hline Amobarbital & $10-30$ & $8-40$ & 30-Hydroxyamobarbital (moderately active) & $30-240 \mathrm{mg}$ & $1,5 \mathrm{~g}$ (lethal) \\
\hline Barbital & $15-30$ & 48 & Excreted almost entirely as unchanged drug & $300-600 \mathrm{mg}$ & 2 g (lethal) \\
\hline Secobarbital & $19-34$ & $8-15$ & $\begin{array}{l}\text { Hydroxylation of both side-chains at the } \mathrm{C} 5 \text {-position with } \\
\text { further oxidation of the omegaposition on the butyl side-chain } \\
\text { (inactive) }\end{array}$ & $100 \mathrm{mg}$ & $2 \mathrm{~g}$ (lethal) \\
\hline
\end{tabular}

flunitrazepam). Toxicological data for selected benzodiazepines in presented in Table 2 .

The pharmacological properties of bartiturates are similar to benzodiazepines [9]. These include confusion, memory impairment, sleepiness, sedation, impaired coordination and impaired thinking during the following the day of administration [9]. Barbiturates are found in forms of capsules, tablets and injectables [9] (Table 3).

Barbiturates' medical purposes are the treatment of insomnia, seizures in cases of epilepsy, as well as sedation [9]. Barbiturates' half-lives can vary from short-term acting of 8 hours for amobarbital, up to 100 hours for phenobarbital. The onset action of barbiturates ranges from 10 minutes to 1 hours. Toxicological data for selected benzodiazepines in presented in Table 4.

Delayed reporting of sexual assaults by the victims, with the worthlessness of collecting blood and/or urine samples for toxicological examination, the lack of accurate data on the substances used by the offender, as well as the uncertainty of the substance use included in the hospital registry, forces us to analyze the action possibility of other sedative-hypnotic drugs with intravenous intake [16-21].

Like most drugs used in DFSA, mixing benzodiazepines or barbiturates with alcohol is likely to potentiate the CNS depressant effects. In this case report, no prior or simultaneous administration of alcohol and a sedativehypnotic substance was found, the intake of drugs being intravenous.

Cannabis is the most commonly misused substance in DFSA cases [22,23], yet in the presented scenarios, neither the respiratory nor the oral administration were invoked; the colour, odor and water insolubility reduce the adminitration posibility chosen by the aggressor [24-26]. Amphetamines and cocaine are not obvious candidates for DFSA due to stimulant properties [24].

As GHB, opioids, antihistamines and antidepressants can induce sedation they have been encountered in DFSA cases [24,27], yet the solubility and ways of administration do not eliminate the usage possibility of these substances by the offender.

\section{Conclusions}

Finally, this report presents a rare case of DFSA. Intravenous administration without primary alcoholic ingestion distinguish this case of pro-active drug facilitated sexual assault from those presented in associated literature.

\section{References}

1.HURLEY, M., PARKER, H., WELLS, D.L., The epidemiology of drug facilitated sexual assault. J Clin Forensic Med 2006;13:181-5

2.SPILLER, H.A., ROGERS, J., SAWYER, T.S., Drug facilitated sexual assault using an over-the-counter ocular solution containing tetrahydrozoline (Visine), Legal Medicine 9 (2007) 192-195

3.PAYNE-J AMES, J., ROGERS, D., Drug-facilitated sexual assault, ladettes, and alcohol, JRSM 95 (2002) 326-327

4.REZLESCU, N., SACHELARIE, L., REZLESCU, L., REZLESCU, E., POPA, P.D., Sintering behaviour and properties of LiZn ferrite doped with PbO, Physica Status Solidi A-Applied Research, 191, nr. 2, 2002, 560570 
5.SACHELARIE, L., REZLESCU, E., DOROFTEI, C., REZLESCU, N., Beneficial effect of small $M g O$ content on some physical properties of a CuZn ferrite, J ournal of Optoelectronics and Advanced Materials, $10, \mathrm{nr} .2,2008,344-347$

6.*** United Nations Office on Drugs and Crime, Guidelines for the Forensic Analysis of Drugs Facilitating Sexual Assault and Other Criminal Acts, (2011) https://www.unodc.org/documents/scientific/ forensic_analys_of_drugs_facilitating_sexual_assault_and_other_criminal acts.pdf.

7.LEBEAU, M., MOZAYANI, A., Drug-facilitated Sexual Assault: A Forensic Handbook, Academic Press, 2001

8.SACHELARIE, L., FARCAS, D.M., DARTU, L., VASILIU, M., DARABA, O., NAZARIE, S., MOCANU, C., BURLUI, V., Comparative study of diseases of the stomatognathic system and specific parameters of osteoporosis, Osteoporosis International, 27, nr. 2, 2016, 845-848 9.*** European Monitoring Centre for Drugs and Drug Addiction, Drug Profiles, (2014) http://www.emcdda.europa.eu/drug-profiles

10.MOFFAT, A.C., OSSELTON, M.D., WIDDOP, B., WATTS, J., Clarke's Analysis of Drugs and Poisons in Pharmaceuticals, Body Fluids and Postmortem Material, fourth ed., Pharmaceutical Press, 2011

11.IOV, T., COSTESCU, M., DIAC, M., TABIAN, D., DAVID, S.M., KNIELING, A., DAMIAN, S.l., Dangerous Chemical Agents: General and OdontoStomatological Aspects with Importance in Forensic Toxicology, Rev. Chim. (Bucharest), 70, no. 5, 2019, p. 1829-1834

12.PERJU-DUMBRAVA, D., RADU, C.C., DAVID, S.M., IOV, T., IOV, C.J ., SANDU, I., ILIESCU, D.B., The Importance of Alcohol Testing by Gas Chromatography vs the Cordebard Classical Method Modified in the Medico Legal Investigation, Rev. Chim. (Bucharest), 69, no. 9, 2018, p. $2407-2410$

13.*** European Pharmacopoeia 7.0, 2010. http://www.fptl.ru/ biblioteka/farmacop/ EP-7.0-2.pdf

14.*** TripSit Factsheets, http://drugs.tripsit.me

15.*** Alcohol and Drug Foundation, Drug Facts, (2017) https:// adf.org.au/drugfacts

16.HUNEA, I., DAMIAN, S.I., RADU, C.C., MOLDOVEANU, S., IOV, T., Postmortem specificity of troponin for acute miocard infarction diagnosis through qualitative dosing from pericardial fluid, Rev. Chim., (Bucharest), 69, no. 9, 2018, p. 2482-2486.
17.KNIELING, A., DAVID, S.M., DAMIAN, S.I., BULGARU-ILIESCU, D., IOV, C.J., Death moment estimation in stillbirth, Romanian Journal of Legal Medicine, 25, nr. 3, 2017, 251-255

18.DUMBRAVA, D.P., RADU, C.C., CHIROBAN, O., BULGARU-ILIESCU, D., IOV, T., DAMIAN, S.I., URECHE, D., Retrograde Extrapolation of Blood Alcohol Concentration A theoretical and practical approach, Rev. Chim. (Bucharest), 70, no. 2, 2019, p. 407-409

19.CHRISTENSEN, H.D., BARNETT, L., CARROLL, F.I., Biological activity of pentobarbital metabolites, J. Pharm. Sci 62 (1973) 1722-1723

20.POPESCU, V., VASLUIANU, E., FORNA, N.C., SANDU, I., BERCU, E., Comparative Study of the FTIR Analysis and the Performances of $\mathrm{N}, \mathrm{N}, \mathrm{N}$-trimethyl Chitosan as Wrinkle-proofing Agent, Rev. Chim. (Bucharest), 64, no. 11, 2013, p. 1284-1294

21.BAHRIN, L.G., LUNGU, N.C., FORNA, N.C., SANDU, I., BIRSA, M.L., Zwitterionic 3-(1,3-Dithiol-2-ylium) phenolates, Rev. Chim. (Bucharest), 64, no. 11, 2013, p. 1343-1346

22.*** Office for National Statistics, Drug Misuse: Findings from the 2014/15 Crime Survey for England and Wales, Statistical Bulletin, 2015 https://w w w.gov.uk/government/uploads/system/uploads/ attachment_data/file/462885/drug-misuse-1415.pdf

23.*** Public Health England, Adult Substance Misuse Statistics from the National Drug Treatment Monitoring System (NDTMS), (2016) http:/ /webarchive. nationalarchives.gov.uk/20170807160807/http:// www.nta.nhs.uk/uploads/ adult-statistics-from-the-national-drugtreatment-monitoring-system- 2014-2015.pdf

24.GRELA, A., GAUTAM, L., COLE, M.D., A multifactorial critical appraisal of substances found in drug facilitated sexual assault cases, Forensic Science International 292 (2018) 50-60

25.RADU, C.C., BULGARU-ILIESC, D., Claims of uniqueness in forensic medicine, Romanian Journal of Legal Medicine, 24, nr. 4, 2016, 343345

26.RADU, C.C., PODILA, C., CAMARASAN, A., BULGARU-ILIESCU, D., PERJU-DUMBRAVA, D., Ethical professional-personal model of making decisions in forensic medicine, Romanian J ournal of Legal Medicine, 25, nr. 3, 2017, 314-316

27.NEGRUSZ, A., JUHASCIK, M., GAENSSLEN, R.E., Estimate of the Incidence of Drugfacilitated Sexual Assault in the U.S., (2005)

Manuscript received: 6.11 .2019 